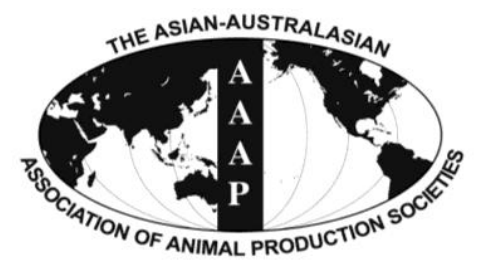

Asian Australas. J. Anim. Sci.

Vol. 26, No. 5 : 646-653 May 2013

http://dx.doi.org/10.5713/ajas.2012.12498

Www.ajas.info

pISSN $1011-2367$ elSSN 1976-5517

\title{
Effect of Water Hyacinth (Eichhornia Crassipes) Silage on Intake and Nutrient Digestibility in Cattle Fed Rice Straw and Cottonseed Cake
}

\author{
Ho Thanh Tham* and Peter Udén ${ }^{1}$ \\ Department of Animal Sciences, Can Tho University, Vietnam
}

\begin{abstract}
Four crossbred Sindhi heifers with an average body weight (BW) of $135 \mathrm{~kg}$ and a mean age of 17 months were used to investigate the effect of feeding different combinations of rice straw and ensiled water hyacinth $(\mathrm{EWH})$ supplemented with a source of protein in the form of cottonseed cake (CSC) on intake and digestibility. Four treatments consisting of graded levels of EWH were arranged in a $4 \times 4$ Latin square. The levels of EWH were set at: 0 (EWH0), 15 (EWH15), 30 (EWH30), and 45\% (EWH45) of an expected total dietary dry matter (DM) intake of $30 \mathrm{~g}$ total DM per kg BW per day. Rice straw was offered ad libitum, while CSC was given at a fixed level of $5 \mathrm{~g} \mathrm{DM} / \mathrm{kg}$ body weight (BW). Voluntary intake and digestibility were measured consecutively in the 4 experimental periods which each lasted 28 days. The crude protein (CP) content of EWH, rice straw and CSC were 174,53 and $370 \mathrm{~g} / \mathrm{kg}$ $\mathrm{DM}$, respectively. Rice straw had the highest neutral detergent fibre (NDFom) content (666 g/kg DM), followed by EWH (503 g/kg $\mathrm{DM}$ ) and the lowest content was $418 \mathrm{~g} / \mathrm{kg} \mathrm{DM}$ in the CSC. The actual EWH contents in the consumed diets were $0,17,32$ and $52 \%$ for EWH0, EWH15, EWH30 and EWH45, respectively. Rice straw intake decreased with level of EWH offered from 3049 for EWH0 to 1014 g/day for EWH45. Crude protein intake was 16, 25 and 33\% higher ( $\mathrm{p}<0.001)$ in EWH15, EWH30 and EWH45 treatments, respectively, as compared to EWH0. Digestibility of organic matter (OM), CP, NDFom and acid detergent fibre (ADFom) increased with increasing level of EWH offered. The highest OM digestibility (72.2\%) was found for treatment EWH45 and the lowest (47.4\%) for treatment EWH0. In spite of similar dietary CP contents, CP digestibility increased by 21 (EWH15), 31 (EWH30) and 40\% (EWH45) with increasing level of EWH in comparison with treatment EWH0. It is concluded that increasing level of EWH in cattle diets considerably improved CP intake and digestibility of nutrients. (Key Words: Cottonseed Cake, Digestibility, Intake, Rice Straw, Water Hyacinth Silage)
\end{abstract}

\section{INTRODUCTION}

Vietnam is predominantly an agricultural economy country based on paddy rice production (NIAH, 2003). An estimated $70 \%$ of the rural population relies almost exclusively on agriculture for their livelihood (Vu, 2007).

With a rapid growth of livestock production in recent years, many researchers have focused on the development of new feed resources to improve animal productivity (Wanapat and Chanthakhoun, 2011). Feed resources in Vietnam consist of some natural pastures and of large quantities of agricultural by-products, mainly rice straw (Ly, 1995). Rice straw is available all year round with a total of

\footnotetext{
* Corresponding Author: Ho Thanh Tham. Tel: +84-(0)7103830786, Fax: +84-(0)710-3830814, E-mail: httham@ctu.edu.vn ${ }^{1}$ Department of Animal Nutrition and Management, Swedish University of Agricultural Sciences, Kungsängen Research Centre, 75323 Uppsala, Sweden.

Submitted Sept. 14, 2012; Accepted Nov. 18, 2012; Revised Jan. 14, 2013
}

25 to 30 million tons produced annually (Chinh and Ly, 2001), but it has a low digestibility and protein content (Van Soest, 2006). Better use of available feed resources, crop residues and low quality roughages should therefore be an important strategy (Devendra et al., 2001) because feed costs dominate animal production, even when household labour is valued at full cost (Nin et al., 2003).

Good quality grass is not readily available in Vietnam and becomes very scarce during the dry season. At the same time, starch and protein sources become more expensive. A number of non-conventional feed resources such as cassava foliage, sugarcane tops, maize, including water hyacinth (WH), are available in Vietnam and neighbouring countries and have become more interesting for the improvement of ruminant production (Devendra, 1985).

Water hyacinth (Eichhornia crassipes) is probably the worst aquatic pest plant in almost all tropical nations (Boyd, 1968). It multiplies rapidly and forms dense mats (Gopal and Goel, 1993) which interfere with waterways, decimates 
aquatic wildlife, creates ideal conditions for diseases and its vectors, etc. (Kushwaha, 2012). However, there are potential benefits from WH such as animal fodder, water purification, fibreboard, biogas, fertilizer and paper production (Lindsey and Hirt, 1999). A number of studies have evaluated $\mathrm{WH}$ as a feed source to beef cattle (Parashar et al., 1999; Thu, 2011), to goats (Kibria et al., 1990; Hira et al., 2002) and to sheep (Baldwin et al., 1975; Abou-Raya et al., 1980). Ensiling appears to be the only feasible means of preserving high moisture crops and WH during periods when drying is not possible (Kellems and Church, 2003).

In countries like Vietnam, where poor quality rice straw is the major roughage source available, WH could offer a better alternative. High growth rate (Gopal, 1987) and a high CP content (Virabalin et al., 1993) makes WH an interesting forage plant.

The objective of this study was to investigate the effect of feeding different combinations of rice straw and ensiled water hyacinth (EWH) supplemented with a source of protein in the form of cottonseed cake (CSC) on intake and digestibility of crossbred Sindhi cattle.

\section{MATERIAL AND METHODS}

\section{Experimental design}

Four treatments consisting of graded levels of EWH were arranged in a $4 \times 4$ Latin square. The basal diet consisted of rice straw, supplemented with CSC to achieve reasonable crude protein levels of the diets. Voluntary intake and digestibility were measured consecutively in the 4 experimental periods which each lasted $28 \mathrm{~d}$. The intake measurements consisted of $5 \mathrm{~d}$ for adaptation to the diets and $14 \mathrm{~d}$ for feed intake measurements. Digestibility was finally measured in a 7-d collection of faeces after $2 \mathrm{~d}$ of adaptation to the adjusted diets.

For measuring intake, rice straw was offered ad libitum, while CSC was given at a fixed level of $5 \mathrm{~g}$ dry matter (DM) $/ \mathrm{kg}$ body weight (BW). The levels of EWH were set at: 0 (EWH0), 15 (EWH15), 30 (EWH30), and 45\% (EWH45) of an expected total dietary DM intake of $30 \mathrm{~g}$ total DM per kg BW per day. For measuring digestibility, diets were adjusted such that rice straw and CSC were fixed at 10 and $5 \mathrm{~g} \mathrm{DM} / \mathrm{kg} \mathrm{BW}$, respectively, and $\mathrm{EWH}$ proportions were set at $0,15,30$ or $45 \%$ of total DM offered.

\section{Experimental animals, feeds and management}

Four crossbred Sindhi heifers (Red Sindhi×local yellow cattle) with an average BW of $135(\mathrm{SD}=9) \mathrm{kg}$ and a mean age of 17 months were used for the experiment to determine voluntary intake and digestibility. The heifers were kept indoors in individual metabolism cages $(1 \times 2 \mathrm{~m})$ and protected against mosquitoes by wire mesh screens covering the barn. Before commencement of the trial, the cattle were treated against internal and external parasites using Vimectin (Vemedim, Can Tho City, Vietnam) and vaccinated against Foot-and-mouth disease (Aphtaeepizooticae) using Aftovax (Merial, Lyon City, France).

Cottonseed cake was fed once daily prior to feeding EWH at 07:00 h. Ensiled water hyacinth was fed at 07:30 and 13:00 h, followed by rice straw at 08:00, 11:00, 16:00 and 19:00 h. Water and commercial mineral blocks (Tithebarn Rockies, Cheshire, England) were available at all times. The latter contained $\mathrm{Mg} 5 \mathrm{~g}, \mathrm{Fe} 1.5 \mathrm{~g}$, Co $50 \mathrm{mg}, \mathrm{Cu}$ $300 \mathrm{mg}$, I $150 \mathrm{mg}$, Mn $200 \mathrm{mg}$, Zn $300 \mathrm{mg}$, Se $10 \mathrm{mg}$ and $\mathrm{Na} 380 \mathrm{~g}$ per $\mathrm{kg}$ block. Rice straw levels were adjusted daily when measuring voluntary intake to ensure an excess level of $10 \%$, based on intake measured the previous day.

Water hyacinths were collected on 8 separate occasions along Tien River in Vinh Long province after 6 to 8 wks of primary growth. Collection started 2 wks prior to the first experimental period and then every 2 wks until the middle of the last period. Petioles were cut 4 to $5 \mathrm{~cm}$ from the base of the plant. Both petiole and leaf fractions were then cut by hand into 4 to $5 \mathrm{~cm}$ pieces, spread at a 6 to $7 \mathrm{~cm}$ depth on plastic sheeting corresponding to a weight of $6 \mathrm{~kg} / \mathrm{m}^{2}$. The material was sun-dried for approximately $8 \mathrm{~h}$ to a DM content of 160 to $200 \mathrm{~g} / \mathrm{kg}$. The wilted material was spread on a plastic sheeting, sprayed with molasses at $40 \mathrm{~g} / \mathrm{kg}$ wilted $\mathrm{WH}$ and then mixed thoroughly. The mixed material was pressed into double plastic bags $(60 \times 98 \mathrm{~cm})$ at a level of 25 to $30 \mathrm{~kg}$ per bag. The inner bag consisted of a woven polyester feed-type bag to protect against breakage during silage compaction. On the outside, there was a clear airtight polyethylene bag (thickness of $0.4 \mathrm{~mm}$ ) closed with a nylon string. All bags were stored under shade at an ambient temperature of 25 to $35^{\circ} \mathrm{C}$. In order to prevent rupturing, the outer bags were opened after 2 or $3 \mathrm{~d}$ to release trapped gas and closed quickly again. Each silage batch was fed after 2 to 4 weeks of ensiling which meant that two batches were fed each experimental period. Ten bags were made in each batch and the cattle consumed two bags every $3 \mathrm{~d}$.

Rice straw had previously been collected in the dry season from a local field at the end of the rice cropping in February. Cottonseed cake was bought from a feed agency in Ho Chi Minh City, Vietnam. It was un-decorticated and not delinted. Both feeds were stored under a roof.

\section{Sample collection and laboratory analyses}

Animals were weighed prior to and after each 14-d feed intake measurement period in the morning before feeding. Mean weights were used to calculated feed allotments. All feeds offered were weighed and recorded daily for each animal and refusals were collected and weighed daily in the morning before feeding.

Faeces were immediately collected when voided and put 
into plastic bags for digestibility measurements. Total daily faecal output was weighed, mixed and $10 \%$ was sampled and stored in a freezer $\left(-20^{\circ} \mathrm{C}\right)$. After $7 \mathrm{~d}$ of faecal collection, individual samples were thawed, pooled and mixed and $10 \%$ was sampled and stored in a freezer awaiting analysis.

Samples of feed offered and refused were taken weekly for analysis of DM, then pooled by animal and period. Feeds, feed residues and faeces were analysed for DM (967.03), crude protein (CP) (984.13) and ash (942.05) according to AOAC (1990). Acid detergent fibre (ADFom) was analysed according to AOAC (1990) (973.18) and neutral detergent fibre (NDFom) was analysed according to Van Soest et al. (1991) without use of amylase or sodium sulfite. Both ADFom and NDFom were expressed exclusive of residual ash. Rice straw lignin (pm) content was analysed using the method of Robertson and Van Soest (1981).

The contents of metabolisable energy (ME) and digestible energy (DE) in the diets (MJ/kg DM) were estimated according to McDonald et al. (2011) and Magalhães et al. (2010), respectively.

$$
\begin{aligned}
& \mathrm{ME}(\mathrm{MJ} / \mathrm{kg} \mathrm{DM})=0.016 \times \mathrm{DOM} \\
& \mathrm{DE}(\mathrm{MJ} / \mathrm{kg} \mathrm{DM})=\mathrm{ME} / 0.82
\end{aligned}
$$

where DOM is digestible organic matter $(\mathrm{g} / \mathrm{kg} \mathrm{DM})$.

\section{Statistical analysis}

Data on the digestibility, ME and DE intakes per day in the digestibility measurement were tested for the linear effect with EWH proportion in the diets as covariate. Intake of OM, CP, ADFom and NDFom were subjected to analysis of variance (ANOVA) using the GLM procedure of Minitab software, version 16.1 (Minitab Inc., 2010) and the model:

$$
\mathrm{y}_{\mathrm{ijk}}=\mu+\mathrm{T}_{\mathrm{i}}+\mathrm{A}_{\mathrm{j}}+\mathrm{P}_{\mathrm{k}}+\mathrm{e}_{\mathrm{ijk}}
$$

where $\mathrm{y}_{\mathrm{ijk}}=$ the dependent variable; $\mu=$ the overall mean; $\mathrm{T}_{\mathrm{i}}$ $=$ the effect of treatment (diet) $(i=1$ to 4$) ; A_{j}=$ the effect of animal $(j=1$ to 4$) ; P_{k}=$ the effect of period $(j=1$ to 4$) ; e_{i j k}$ $=$ the random error.

\section{RESULTS}

\section{Chemical composition of feeds and diets}

When bags were opened after 2 to 4 wks of ensiling, no free liquid was found in any of the bags. Silage colour was greenish yellow and changed to a brownish yellow colour after 2 wks of storage. Some mould was found on the top of the silage in a few bags while most bags had little or no mould growth. All mouldy silage was discarded before feeding.

The chemical composition of the experimental feeds is shown in Table 1. After wilting, the WH DM content was still low (166 g/kg DM). The CP content of EWH, rice straw and CSC were 174, 53 and $370 \mathrm{~g} / \mathrm{kg} \mathrm{DM}$, respectively. The ash content of EWH and rice straw were high and on average 169 and 142 g/kg DM, respectively. Rice straw had the highest NDFom content (666 g/kg DM), followed by EWH (503 g/kg DM) and the lowest content was $418 \mathrm{~g} / \mathrm{kg}$ $\mathrm{DM}$ in the CSC.

\section{Feed intake measurements}

There were differences in the composition of the diets respect to $\mathrm{OM}, \mathrm{CP}, \mathrm{ADFom}$ and NDFom (Table 2). The actual EWH contents in the consumed diets were EWH0, 0; EWH15, 17; EWH30, 32 and EWH45, 52\%. Rice straw intake decreased with level of EWH offered from 3049 for EWH0 to $1014 \mathrm{~g} / \mathrm{d}$ for EWH45. No treatment effect was observed $(p>0.05)$ in total feed intake. Daily total DM intake in percent of BW was relatively constant between 2.5 and 2.7 and did not differ among treatments ( $>0.05)$. Crude protein intake was 16,25 and $33 \%$ higher $(\mathrm{p}<0.001)$ in EWH15, EWH30 and EWH45 treatments, respectively, as compared to EWH0 (Table 3).

\section{Digestibility measurements}

The composition of the diets and energy intakes during the digestibility measurements is presented in Table 2. The $\mathrm{CP}$ content was similar in all diets $(\mathrm{p}=0.254)$ whereas

\begin{tabular}{|c|c|c|c|c|c|c|c|c|}
\hline \multirow{2}{*}{ Item $^{\mathrm{a}}$} & \multicolumn{2}{|c|}{ Ensiled water hyacinth } & \multicolumn{2}{|c|}{ Rice straw } & \multicolumn{2}{|c|}{ Sugarcane molasses } & \multicolumn{2}{|c|}{ Cottonseed cake } \\
\hline & Mean & SD & Mean & SD & Mean & SD & Mean & SD \\
\hline Dry matter & 166 & 8.0 & 916 & 11.9 & 814 & 4.22 & 881 & 5.2 \\
\hline Crude protein & 174 & 3.5 & 53 & 2.6 & 33 & 0.91 & 370 & 5.8 \\
\hline Ash & 169 & 7.2 & 142 & 2.5 & 64 & 0.47 & 56 & 1.7 \\
\hline ADFom & 319 & 15.8 & 389 & 2.9 & nd & - & 300 & 7.5 \\
\hline NDFom & 503 & 21.5 & 666 & 4.3 & nd & - & 418 & 4.0 \\
\hline Lignin (pm) & nd & - & 76 & - & nd & - & nd & - \\
\hline
\end{tabular}

Table 1. Dry matter and chemical composition $(\mathrm{g} / \mathrm{kg} \mathrm{DM})$ of the wilted water hyacinth, rice straw, sugarcane molasses and cottonseed cake

$\overline{{ }^{a}}$ ADFom $=$ Acid detergent fibre; NDFom $=$ Neutral detergent fibre; Lignin $(\mathrm{pm})=$ Lignin determined by oxidation of lignin with permanganate; $\mathrm{nd}=$ Not determined. 
Table 2. Composition of diets from the intake and digestibility measurements ( $\mathrm{g} / \mathrm{kg}$ dry matter or as otherwise stated)

\begin{tabular}{|c|c|c|c|c|c|c|}
\hline & EWH0 & EWH15 & EWH30 & EWH45 & SEM & $\mathrm{p}$ \\
\hline \multicolumn{7}{|c|}{ Intake measurements } \\
\hline $\mathrm{OM}$ & $875^{\mathrm{a}}$ & $870^{\mathrm{b}}$ & $867^{\mathrm{b}}$ & $861^{\mathrm{c}}$ & 0.8 & $<0.001$ \\
\hline $\mathrm{CP}$ & $113^{\mathrm{c}}$ & $134^{\mathrm{bc}}$ & $155^{\mathrm{ab}}$ & $179^{\mathrm{a}}$ & 5.1 & 0.001 \\
\hline ADFom & $372^{\mathrm{a}}$ & $360^{\mathrm{b}}$ & $347^{\mathrm{c}}$ & $335^{\mathrm{d}}$ & 1.9 & $<0.001$ \\
\hline NDFom & $619^{\mathrm{a}}$ & $591^{\mathrm{b}}$ & $563^{\mathrm{c}}$ & $530^{\mathrm{d}}$ & 4.4 & $<0.001$ \\
\hline \multicolumn{7}{|c|}{ Digestibility measurements } \\
\hline $\mathrm{OM}$ & $885^{\mathrm{a}}$ & $873^{\mathrm{b}}$ & $865^{\mathrm{c}}$ & $861^{\mathrm{c}}$ & 1.6 & $<0.001$ \\
\hline $\mathrm{CP}$ & 148 & 153 & 157 & 166 & 5.8 & 0.254 \\
\hline ADFom & $364^{\mathrm{a}}$ & $354^{\mathrm{ab}}$ & $347^{\mathrm{bc}}$ & $340^{\mathrm{c}}$ & 2.6 & 0.003 \\
\hline NDFom & $581^{\mathrm{a}}$ & $564^{\mathrm{b}}$ & $552^{\mathrm{c}}$ & $546^{\mathrm{c}}$ & 1.9 & $<0.001$ \\
\hline \multicolumn{7}{|c|}{ Energy content (MJ/kg DM) } \\
\hline $\mathrm{DE}$ & $8.2^{\mathrm{b}}$ & $9.6^{\mathrm{b}}$ & $10.3^{\mathrm{ab}}$ & $12.1^{\mathrm{a}}$ & 0.5 & 0.009 \\
\hline ME & $6.7^{\mathrm{b}}$ & $7.9^{\mathrm{b}}$ & $8.4^{\mathrm{ab}}$ & $9.9^{\mathrm{a}}$ & 0.4 & 0.009 \\
\hline
\end{tabular}

$\mathrm{EWH}=$ Ensiled water hyacinth; $\mathrm{OM}=$ Organic matter; $\mathrm{CP}=$ Crude protein; ADFom = Acid detergent fibre; NDFom = Neutral detergent fibre; $\mathrm{DE}=$ digestible energy; $\mathrm{ME}=$ Metabolisable energy; $\mathrm{SEM}=$ Standard error of means.

${ }_{a, b, c, d}$ Means within rows with different letters differ $(\mathrm{p}<0.05)$.

Table 3. Intake and digestibility of the diets from the intake and digestibility measurements

\begin{tabular}{|c|c|c|c|c|c|c|}
\hline & EWH0 & EWH15 & EWH30 & EWH45 & SEM & $\mathrm{p}$ \\
\hline \multicolumn{7}{|l|}{ Intake measurement } \\
\hline \multicolumn{7}{|l|}{ Intake (g/d) } \\
\hline Cottonseed cake & 723 & 723 & 724 & 702 & 17 & 0.749 \\
\hline Ensiled water hyacinth & 0 & 637 & 1,186 & 1,853 & - & - \\
\hline Rice straw & $3,049^{\mathrm{a}}$ & $2,454^{\mathrm{ab}}$ & $1,772^{\mathrm{bc}}$ & $1,014^{\mathrm{c}}$ & 194 & 0.001 \\
\hline $\mathrm{DM}$ & 3,772 & 3,814 & 3,682 & 3,569 & 201 & 0.831 \\
\hline $\mathrm{DM}(\% \mathrm{BW})$ & 2.6 & 2.7 & 2.6 & 2.5 & 0.15 & 0.773 \\
\hline $\mathrm{OM}$ & 3,299 & 3,318 & 3,190 & 3,073 & 173 & 0.742 \\
\hline $\mathrm{CP}$ & $428^{\mathrm{c}}$ & $508^{\mathrm{b}}$ & $568^{\mathrm{ab}}$ & $636^{\mathrm{a}}$ & 15 & $<0.001$ \\
\hline ADFom & 1,403 & 1,372 & 1,280 & 1,195 & 78 & 0.311 \\
\hline NDFom & 2,335 & 2,255 & 2,072 & 1,891 & 131 & 0.180 \\
\hline \multicolumn{7}{|l|}{ Digestibility measurement } \\
\hline \multicolumn{7}{|l|}{ Intake $(\mathrm{g} / \mathrm{d})$} \\
\hline Cottonseed cake & 767 & 767 & 735 & 724 & 17 & - \\
\hline Ensiled water hyacinth & 0 & 622 & 1,314 & 1,968 & - & - \\
\hline Rice straw & 1,532 & 1,532 & 1,474 & 1,464 & 18 & - \\
\hline DM & $2,299^{\mathrm{d}}$ & $2,921^{\mathrm{c}}$ & $3,523^{\mathrm{b}}$ & $4,156^{\mathrm{a}}$ & 51 & - \\
\hline $\mathrm{DM}(\% \mathrm{BW})$ & $1.5^{\mathrm{c}}$ & $1.9^{\mathrm{c}}$ & $2.4^{\mathrm{b}}$ & $2.8^{\mathrm{a}}$ & 0.02 & - \\
\hline $\mathrm{OM}$ & $2,034^{\mathrm{d}}$ & $2,551^{\mathrm{c}}$ & $3,047^{\mathrm{b}}$ & $3,577^{\mathrm{a}}$ & 47 & - \\
\hline $\mathrm{CP}$ & $335^{\mathrm{c}}$ & $444^{\mathrm{bc}}$ & $552^{\mathrm{b}}$ & $689^{\mathrm{a}}$ & 25 & - \\
\hline ADFom & $838^{\mathrm{d}}$ & $1,037^{\mathrm{c}}$ & $1,222^{\mathrm{b}}$ & $1,412^{\mathrm{a}}$ & 14 & - \\
\hline NDFom & $1,336^{\mathrm{d}}$ & $1,650^{\mathrm{c}}$ & $1,944^{\mathrm{b}}$ & $2,268^{\mathrm{a}}$ & 33 & - \\
\hline Digestibility (\%) & & & & & --- Lil & ect ------ \\
\hline $\mathrm{OM}$ & $47.4^{\mathrm{b}}$ & $56.3^{\mathrm{b}}$ & $60.8^{\mathrm{ab}}$ & $72.2^{\mathrm{a}}$ & 3.0 & $<0.001$ \\
\hline $\mathrm{CP}$ & $57.3^{\mathrm{b}}$ & $66.8^{\mathrm{a}}$ & $71.7^{\mathrm{a}}$ & $75.1^{\mathrm{a}}$ & 1.8 & $<0.001$ \\
\hline ADFom & $31.1^{\mathrm{b}}$ & $43.6^{\mathrm{ab}}$ & $44.0^{\mathrm{ab}}$ & $49.1^{\mathrm{a}}$ & 3.0 & 0.005 \\
\hline NDFom & $37.0^{\mathrm{b}}$ & $47.0^{\mathrm{ab}}$ & $53.8^{\mathrm{a}}$ & $61.8^{\mathrm{a}}$ & 3.1 & $<0.001$ \\
\hline $\mathrm{DE}(\mathrm{MJ} / \mathrm{d})$ & $18.6^{\mathrm{c}}$ & $28.3^{\mathrm{b}}$ & $36.2^{\mathrm{b}}$ & $50.3^{\mathrm{a}}$ & 1.8 & $<0.001$ \\
\hline $\mathrm{ME}(\mathrm{MJ} / \mathrm{d})$ & $15.3^{\mathrm{c}}$ & $23.2^{\mathrm{b}}$ & $29.7^{\mathrm{b}}$ & $41.3^{\mathrm{a}}$ & 1.5 & $<0.001$ \\
\hline
\end{tabular}

$\mathrm{EWH}=$ Ensiled water hyacinth; $\mathrm{DM}=$ Dry matter; $\mathrm{OM}=$ Organic matter; $\mathrm{CP}=$ Crude protein; ADFom = Acid detergent fibre;

NDFom $=$ Neutral detergent fibre; $\mathrm{DE}=$ Digestible energy; $\mathrm{ME}=$ Metabolisable energy; $\mathrm{SEM}=$ Standard error of means.

$\mathrm{a}, \mathrm{b}, \mathrm{c}, \mathrm{d}$ Means within rows with different letters differ $(\mathrm{p}<0.05)$. 
NDFom and ADFom contents decreased somewhat from 581 to 546 and from 364 to $340 \mathrm{~g} / \mathrm{kg}$ DM, respectively. The estimated DE and ME values in the diets differed among the diets $(p<0.05)$ and was $32 \%$ higher in EWH45 compared with EWH0.

There were no refusals of CSC, rice straw and EWH in any treatments. As shown in Table 3, there were clear effects of treatment on OM, CP, NDFom and ADFom digestibility, all of which increased with increasing level of EWH offered. The highest OM digestibility (72.2\%) was found for treatment EWH45 and the lowest (47.4\%) for treatment EWH0. In spite of similar dietary CP contents, CP digestibility increased by 21 (EWH15), 31 (EWH30) and $40 \%$ (EWH45) with increasing level of EWH in comparison with treatment EWHO.

\section{DISCUSSION}

The feeds chosen for this study were CSC, rice straw and $\mathrm{WH}$ as they are abundant and available all year round in Vietnam. Cottonseed is composed of $32 \%$ hull (Silverstein et al., 2007) which are removed during processing by modern factories but not in the present study. The NDF content in rice straw was lower than the value reported by Thu and Udén (2001). The difference could be a result of expressing NDF exclusive of residual ash in the present study. If the ash, which mostly consists of silica (Van Soest, 2006), is included, our value would be approximately $800 \mathrm{~g} / \mathrm{kg}$ DM. The cell wall constituents of rice straw, measured as NDF with ash included, can be as high $860 \mathrm{~g} / \mathrm{kg} \mathrm{DM}$ and is very resistant to fermentation (Doyle et al., 1986). The NDFom content in EWH was lower than the value of $527 \mathrm{~g} / \mathrm{kg} \mathrm{DM}$ as presented by Abdelhamid and Gabr (1991).

Lignin, followed by silica and cutin, are the primary limiting factors of digestibility (Van Soest, 1981). The rice straw used in this study was relatively high in lignin (pm) with a value of $76 \mathrm{~g} / \mathrm{kg} \mathrm{DM}$ in comparison with $52 \pm 16 \mathrm{~g} / \mathrm{kg}$ as reviewed by Van Soest (2006). Rice straw is also known to be high in silica compared with other straws with levels of approximately $130 \mathrm{~g} / \mathrm{kg}$ (Van Soest, 2006). The EWH composition was considerably more favourable than that of the rice straw with $>3$ times higher protein content and $24 \%$ lower NDFom but with a somewhat higher ash content (Table 1). Lignin content was not measured but varied between 30 to $69 \mathrm{~g} / \mathrm{kg}$ DM in a previous study (Tham et al., 2012). Abdelhamid and Gabr (1991) found in vitro organic matter digestibility (IVOMD) of fresh $\mathrm{WH}$ was $52 \%$, and in a previous study (Tham et al., 2012) we found IVOMD values for leaf and petiole varying between approximately 40 to $65 \%$. Rice straw in vivo $\mathrm{OM}$ digestibility varied between 31 to $60 \%$ in data compiled by Van Soest (2006).

There was little or no mould growth in the silage bags showed that water hyacinth can be successfully ensiled with molasses at $40 \mathrm{~g} / \mathrm{kg}$ material. Similar findings were also reported by El-Serafy et al. (1989). It is not known if molasses or other soluble carbohydrate sources are required, and we also do not know what the long-term storage effects may be on silage quality. Baldwin et al. (1974) found an immediate acceptance of EWH by cattle, while gradual adaptation was required in the present study to obtain the planned intake. Normally, at least 10 days is recommended for cattle to become accustomed to new feeds before voluntary intake is recorded (Forbes, 2007).

Considerable variation in digestibility existed within treatments and the overall animal SD was 5.1. In spite of that, there was a dramatic effect of increasing EWH level in the diet on digestibility of all diet components was surprising $(p<0.001)$. Particularly, the increased CP digestibility was unexpected in light of similar CP levels were among treatments. If the rice straw and CSC digestibility was assumed constant in all diets, EWH digestibility could be estimated from the slope of the regression of digested EWH upon amount consumed. Values for OM and NDFom were, however, unrealistic and approximately $93 \%$ as shown in Figure 1. Tham et al.

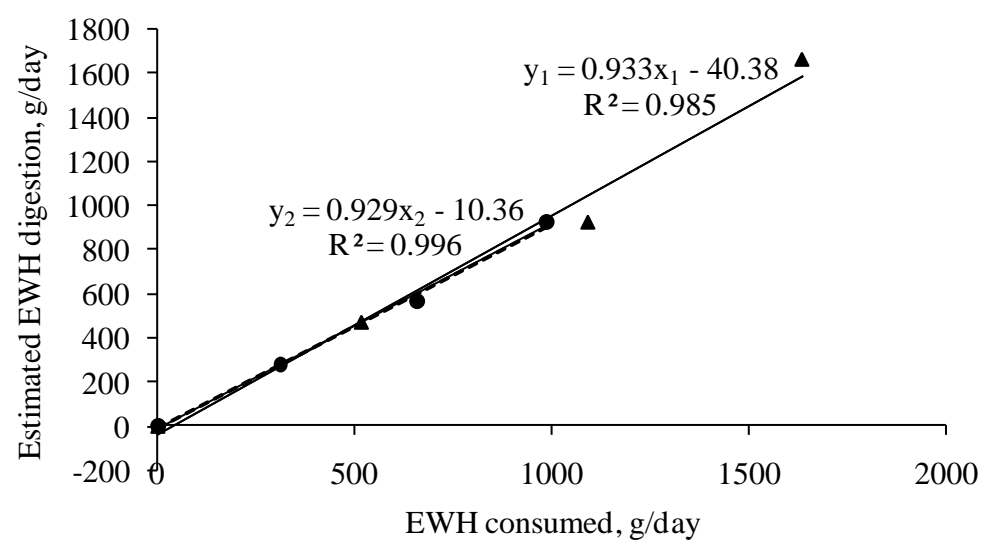

Figure 1. Regression between OM $\left(\mathrm{y}_{1}\right)$, NDFom $\left(\mathrm{y}_{2}\right)$ consumed and digested coming from EWH in cattle fed different levels of EWH. 
(2012) found that WH growing in the river habitat had IVOM digestibilities of 48 and $62 \%$ in leaf and petiole, respectively, which were considerably lower than values estimated here.

Increasing EWH proportion in the diets resulted in a reduced rice straw intake, yielding similar intakes among treatments. Voluntary intake of ruminants is determined by two main factors, the ingestibility of the forage and the intake capacity of the animal (Dulphy and Demarquilly, 1994). Voluntary intake can also be positively related to the DM content of silages (Forbes, 2007). In the present study, DM content of EWH was relatively low (166 g/kg) which could have had a reducing effect on intake. Water hyacinth is characterised by bulbous and elongated petioles containing large air cells enabling the plant to float on water (Parsons and Cuthbertson, 2001). However, it is not known whether this has any specific negative effect on intake. According to Van Soest (1994), the primary component of the feed regulating intake is the plant cell wall content or NDF. When the cell wall content of a forage increases, the digestion rate decreases, mastication increases per unit feed and intake is reduced (Dulphy and Demarquilly, 1994).

When large refusals of feeds are permitted, cattle can select a more digestible diet than when restricted (Van Soest, 1994). In the present study, the animals could therefore choose the better quality EWH instead of rice straw. Intake of silage does not always appear to be positively related to digestibility (Forbes, 2007) which digestibility depends on both cell wall content and its availability to digestion (Van Soest, 1994). Although OM intakes tended to decrease with increasing EWH level in the diets, OM digestibility increased by 16, 22 and $34 \%$ for EWH15, EWH30 and EWH45 treatments, respectively, as compared to treatment EWH0. Islam et al. (2009) reported that OM digestibility increased with increasing levels of wilted $\mathrm{WH}$ in rice strawbased diet.

From the intake measurements, it was not possible to calculated energy intakes. Instead, this was done on data from the digestibility measurements. The energy concentration of the diet is normally considered as the first limiting nutrient of beef production. Daily ME requirement of cattle for maintenance and live weight (LW) gain in the tropics were tabulated by Kearl (1982) and from this table, an equation of ME requirements for cattle weighing $150 \mathrm{~kg}$ were estimated as: $\mathrm{y}=39.75 \mathrm{x}-874.5$, where $\mathrm{y}=\mathrm{LW}$ gain $(\mathrm{g} / \mathrm{d}) ; \mathrm{x}=\mathrm{ME}$ intake $(\mathrm{MJ} / \mathrm{d})$. A similar equation for $\mathrm{CP}$ was also established, but these requirements were always less limiting, relative to ME. Based on actual ME intake and the equation above, potential LW changes of the cattle were estimated at -266, 48, 306 and $767 \mathrm{~g} / \mathrm{d}$ for the EWH0, EWH15, EWH30 and EWH45 treatments, respectively.

Although annual expenditure in physical removal of
WH amounts to several million US dollars in India (Inderjit, 2005), manual labour for harvesting aquatic plants as WH is inexpensive in many tropical countries. Harvesting WH by hand would probably be economical in a number of countries (Boyd, 1968). A system based on the harvest of WH has a potential for removing nutrients from effluents and natural waters (Boyd, 1970), use as a feed resource to livestock feed and an effective physical control method of important waterways.

\section{CONCLUSIONS}

It is concluded that EWH offered to cattle resulted in a decreased rice straw intake. Crude protein intake was higher than in the treatments with the addition of EWH. Digestibility of OM, CP, NDFom and ADFom increased with increasing level of EWH offered. It seems likely that EWH at levels of at least $50 \%$ of the diet has the potential to support ME for reasonable LW gains in cattle. During scarcity of high quality feeds in the dry season, ensiled WH could also be a particularly viable alternative in ruminant diets. However, practical harvesting and wilting systems need to develop and additional growth studies must be conducted with ensiled and fresh WH before recommending WH feeding in practice.

\section{ACKNOWLEDGEMENTS}

The authors gratefully acknowledge the Sida-SAREC Mekong Basin Animal Research Network (MEKARN) for financial support of this research. The authors wish to thank Mr. Pham Truong Giang and Ms. Pham My Ngoan for assistance in taking care of the experimental animals and chemical analyses; to Mrs. Le Thi Kim Trang for her enthusiastic help to choose a source of high quality cottonseed cake. A special thanks to Dr. Ngo Van Man for his valuabe support of this work.

\section{REFERENCES}

Abdelhamid, A. M. and A. A. Gabr. 1991. Evaluation of water hyacinth as a feed for ruminants. Arch. Anim. Nutr. 41:745756.

Abou-Raya, A. K., M. K. Hathout, Y. L. El-Talty and A. M. AbdelKhabir. 1980. Utilization of water hyacinth as animal feed: II. Evaluation of wilted shoots in metabolism trials with sheep with reference to N, Ca, Na and K balances. Agric. Res. Rev. 58:49-60.

AOAC. 1990. Official methods of analysis (15th ed.). Association of Official Analytical Chemists Inc., Virginia, USA.

Baldwin, J. A., J. F. Hentges and L. O. Bagnall. 1974. Preservation and cattle acceptability of water hyacinth silage. Hyacinth Control J. 12:79-81.

Baldwin, J. A., J. F. Hentges, L. O. Bagnall and R. L. Shirley. 1975. 
Comparison of pangolagrass and water hyacinth silages as diets for sheep. J. Anim. Sci. 40:968-971.

Boyd, C. E. 1968. Fresh-water plants: a potential source of protein. Econ. Bot. 22:359-368.

Boyd, C. E. 1970. Vascular aquatic plants for mineral nutrient removal from polluted waters. Econ. Bot. 24:95-103.

Chinh, B. V. and L. V. Ly. 2001. Identification of some levels of urea applied for treatment of rice straw using as feed for dairy and growing cattle. In: Proceeding on improved utilization of by-products for animal feeding in Vietnam, 28-30 March, 2001, pp. 20-26.

Devendra, C. 1985. Non-conventional Feed Resources in Asia and the Pacific, 2nd edn., FAO Regional Office for Asia and the Pacific, Bangkok, Thailand.

Devendra, C., C. Sevilla and D. Pezo. 2001. Food-feed systems in Asia - Review. Asian Australas. J. Anim. Sci. 14:733-745.

Doyle, P. T., C. Devendra and G. R. Pearce. 1986. Rice straw as a feed for ruminants. International Development Program of Australian Universities and Colleges Limited (IDP).

Dulphy, J. P. and C. Demarquilly. 1994. The regulation and prediction of feed intake in ruminants in relation to feed characteristics. Livest. Prod. Sci. 39:1-12.

El-Serafy, A. M., M. Shoukry, S. Mansour, H. S. Soliman, H. M. Aly and M. A. El-Ashry. 1989. A new potential roughage source for ruminants in Egypt: Processing and utilization of water hyacinth as hay or silage. In: Ruminant production in the dry subtropics: constraints and potentials. Proceedings of the International Symposium on the Constraints and Possibilities of Ruminant Production in the Dry Subtropics (MOA of Egypt, ESAP, EAAP, FAO, ICAMAS, WAAP), Cairo, Egypt, 5-7 November 1988. pp. 153-155.

Forbes, J. M. 2007. Voluntary Food Intake and Diet Selection in Farm Animals, 2nd ed. CABI Publishing, Wallingford, Oxfordshire, UK.

Gopal, B. 1987. Water Hyacinth. Elsevier, Amsterdam, The Netherlands, p. 471.

Gopal, B. and U. Goel. 1993. Competition and allelopathy in aquatic plant communities. Bot. Rev. 59:155-210.

Hira, A. K., M. Y. Ali, M. Chakraborty, M. A. Islam and M. R. Zaman. 2002. Use of water-hyacinth leaves (Eichhorina crassipes) replacing Dhal grass (Hymenachne pseudointerrupta) in the diet of goat. Pakistan J. Biol. Sci. 5:218-220.

Inderjit. 2005. Invasive Plants: Ecological and agricultural aspects. Birkhäuser Verlag, Basel, Switzerland.

Islam, S., M. J. Khan and M. N. Islam. 2009. Effect of feeding wilted water hyacinth (Eichhornia crassipes) on the performance of growing bull cattle. Indian J. Anim. Sci. 79:494-497.

Kearl, L. C. 1982. Nutrient requirements of ruminants in developing countries. International Feedstuffs Institute, Utah Agricultural Experiment Station, Utah State University, Logan, Utah 84322, USA, pp. 71-88.

Kellems, R. O. and D. C. Church. 2003. Livestock Feeds and Feeding, 5th ed., Prentice Hall, Upper Saddle River, New Jersey, USA.

Kibria, S. S., D. B. Roxas and S. K. Ranjhan. 1990. Ruminant feed based on water-hyacinth: short-term effect on the growth of goats. Indones. J. Trop. Agric. 2:51-53.
Kushwaha, S. P. S. 2012. Remote sensing of invasive alien plant species. In: Invasive Alien Plants: An Ecological Appraisal for the Indian Subcontinent (Ed. J. R. Bhatt, J. S. Singh, S. P. Singh, R. S. Tripathi and R. K. Kohli). CABI International, United Kingdom, 131-138.

Lindsey, K. and H.-M. Hirt. 1999. Use water hyacinth. A Practical Handbook of Uses for the Water Hyacinth from Across The World. Marianum Press, Kisubi, Uganda.

Ly, L. V. 1995. Ruminant production in Vietnam and development of forage in smallholder farm. In: Enhancing Sustainable Livestock-crop Production in Smallholder Farming Systems. Proceedings of the Fourth Meeting of Forage Regional Working Group on Grazing and Feed Resources of Southeast Asia, Nha Trang, Vietnam, 20-24 March 1995. pp. 57-62.

Magalhães, K. A., S. C. Valadares Filho and E. Detmann, et al. 2010. Evaluation of indirect methods to estimate the nutritional value of tropical feeds for ruminants. Anim. Feed Sci. Technol. 155:44-54.

McDonald, P., R. A. Edwards, J. F. D. Greenhalgh, C. A. Morgan, L. A. Sinclair and R. G. Wilkinson. 2011. Animal Nutrition. 7th edn. Pearson, Harlow, England.

Minitab Inc. 2010. Minitab statistical software, version 16.1.0. State College, Pennsylvania, USA.

NIAH. 2003. The vietnam national country report on animal genetic resources. National Institute of Animal Husbandry, Ha Noi, Vietnam.

Nin, A., M. L. Lapar and S. Ehui. 2003. Globalization, trade liberalization and poverty alleviation in Southeast Asia: the case of the livestock sector in Vietnam. In: The 6th annual conference on global economic analysis, June 12-14, 2003, Scheveningen, The Hague, The Netherlands. pp. 1-38.

Parashar, S. K., N. K. Rajora and L. S. Jain. 1999. Utilization of water hyacinth (Eichhornia crassipes) by growing crossbred calves. Indian J. Dairy Sci. 52:320-323.

Parsons, W. T. and E. G. Cuthbertson. 2001. Noxious Weeds of Autralia, 2nd edn. CSIRO Publishing.

Robertson, J. B. and P. J. Van Soest. 1981. The detergent system of analysis and its application to human foods. In: The Analysis of Dietary Fibre in Food (Ed. W. P. T. James and O. Theander), Marcel Dekker Inc., New York, USA, 123-158.

Silverstein, R. A., Y. Chen, R. R. Sharma-Shivappa, M. D. Boyette and J. Osborne. 2007. A comparison of chemical pretreatment methods for improving saccharification of cotton stalks. Bioresour. Technol. 98:3000-3011.

Tham, H. T., N. V. Man and P. Udén. 2012. Biomass yield and nutritive value of water hyacinth (Eichhornia crassipes) grown in two habitats as affected by cut and cutting interval. Grassland Sci. (In press).

Thu, N. V. 2011. Effects of water hyacinth (Eichhornia crassipes) in local cattle diets on nutrient utilization, rumen parameters and microbial protein synthesis. In: SAADC 2011 strategies and challenges for sustainable animal agriculture-crop systems, Volume III: full papers. Proceedings of the $3^{\text {rd }}$ International Conference on sustainable animal agriculture for developing countries, Nakhon Ratchasima, Thailand, 26-29 July, 2011, pp. 422-426.

Thu, N. V. and P. Udén. 2001. Effect of urea-molasses cake supplementation of swamp buffaloes fed rice straw or grasses on rumen environment, feed degradation and intake. Asian 
Australas. J. Anim. Sci. 14:631-639.

Van Soest, P. J. 1981. Limiting factors in plant residues of low biodegradability. Agric. Environ. 6:135-143.

Van Soest, P. J. 1994. Nutritional ecology of the ruminant, 2nd ed. Cornell University Press, Ithaca, New York.

Van Soest, P. J. 2006. Rice straw, the role of silica and treatments to improve quality. Anim. Feed Sci. Technol. 130:137-171.

Van Soest, P. J., J. B. Robertson and B. A. Lewis. 1991. Methods for dietary fibre, neutral detergent fibre and non-starch polysaccharides in relation to animal nutrition. J. Dairy Sci. 74:3583-3597.

Virabalin, R., B. Kositsup and H. Punnapayak. 1993. Leaf protein concentrate from water hyacinth. J. Aquat. Plant Manage. 31:207-209.
Vu, D. D. 2007. Use of urea molasses multinutrient blocks for improving cattle productivity in Viet Nam. In: Feed supplementation blocks: Urea-molasses multinutrient blocks: Simple and effective feed supplement technology for ruminant agriculture (Ed. H. P. S. Makkar, M. Sánchez and A. W. Speedy). Rome, Food and Agriculture Organization of the United Nations, pp. 137-148.

Wanapat, M. and V. Chanthakhoun. 2011. Development of feed resources for the sustainable livestock production in the tropics. In: SAADC 2011 strategies and challenges for sustainable animal agriculture-crop systems, Volume I: Invited papers. Proceedings of the 3rd International Conference on sustainable animal agriculture for developing countries, Nakhon Ratchasima, Thailand, 26-29 July, 2011, pp. 11-20. 